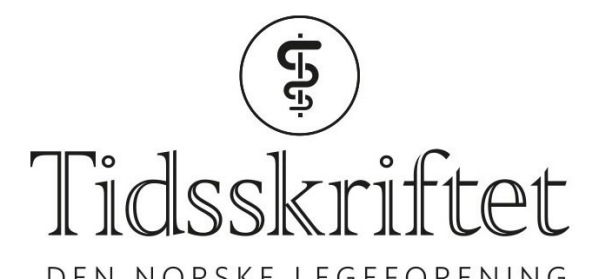

DEN NORSKE LEGEFORENING

\title{
Hva er egentlig helsekompetanse?
}

SPRÅKSPALTEN

\section{ERLEND HEM}

E-post: erlend.hem@medisin.uio.no

Erlend Hem er professor dr.med., fagsjef og redaktør for Tidsskriftets språkspalte.

Det engelske uttrykket health literacy har hittil manglet en norsk term. Kanskje helsekompetanse kan fungere.

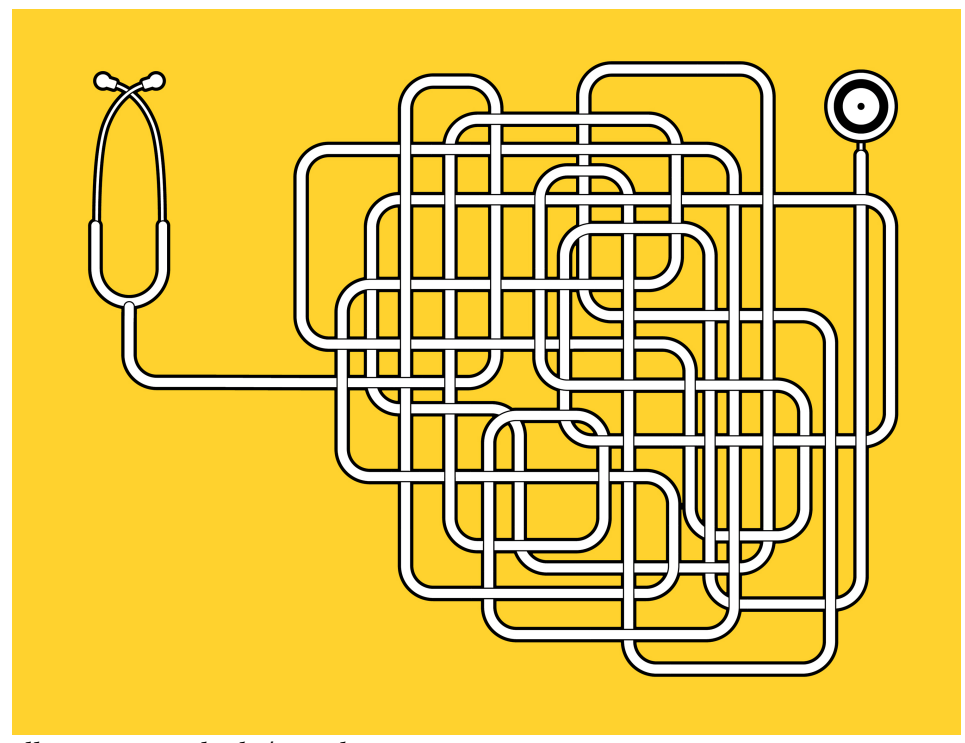

Illustrasjon: alashi/iStock

Helsekompetanse handler om å forstå, vurdere og anvende helseinformasjon. Det skal gjøre pasienter i stand til å bruke helsetjenester på en fornuftig måte (1). Kanskje kan det bidra til mindre feilbruk, overdiagnostikk og overbehandling. Behovet for helsekompetanse er $\emptyset$ kende fordi moderne medisin blir stadig vanskeligere å orientere seg $\mathrm{i}(2,3)$.

\section{Mange muligheter}

Våren 2019 lagde Helse- og omsorgsdepartementet en ny strategi på feltet og foreslo helsekompetanse som norsk betegnelse for health literacy (2). «Det finnes flere norske begrepsvarianter; helsefremmende allmenndannelse, helsekunnskap, helseforståelse, helseinformasjonsforståelse, helserelatert informasjonskompetanse, helsekompetanseog helseinnsikt», skrev departementet (2). De kunne ha listet opp enda noen flere, som helselitterasitet og helsekyndighet.

«Både helsekunnskap og helseforståelse, som er de mest aktuelle andre kandidatene, vurderes som for snevre og omfatter heller ikke det å gjøre en aktiv handling på samme 
måte som kompetansebegrepet gjør», fremholdt departementet (2). Regjeringens nye strategi kom derfor til å hete Strategi for å øke helsekompetansen i befolkningen $(2,4)$.

Helse- og omsorgsdepartementet hevdet altså at helsekompetanse er den mest dekkende termen for health literacy. Det trenger ikke være slik. I Sverige har man valgt å bruke hälsolitteracitet (2), og Språkrådet har påpekt at helsekompetanse er tvetydig på norsk (5).

\section{Omfattende innhold}

Tvilen står om ordet literacy. I engelskordboka blir det forklart som evnen til å til å lese og skrive. Motsatsen illiteracy betyr analfabetisme. Men dette er den snevre forståelsen (6). Ordet omfatter ifølge Store Norske Leksikon også «et sett av skriftspråklige ferdigheter som gjør at man kan forstå, skape, kommunisere, orientere seg og delta i samfunn som er i endring». Termen rommer et stort alvor: «FN definerer literacy som en menneskerett, fordi det er en forutsetning både for å ta til seg kunnskap og delta i demokratiet» (6).

Oxford English Dictionary forklarer literacy også som «competence or knowledge in a particular area» og nevner som eksempler computer literacy og cultural literacy. Sånn sett gir det mening å snakke om helse som et område man har kompetanse eller kunnskap om.

Den engelske termen rommer flere elementer. Skal man ha helsekompetanse, må man både skaffe, vurdere og forstå informasjon. Det er ikke for alle. Sårbare gruppers forutsetninger blir sjelden problematisert. Og sårbare er vi jo gjerne når vi er syke.

Det finnes flere definisjoner av health literacy $(1,5)$. Det er nå over 10 ooo treff i PubMed på denne termen, så godt som alle siden 1995 (per 19.5.2020). Og flere vil det bli.

Når uttrykket skal brukes på norsk, kan det engelske settes i parentes bak første gang det nevnes i teksten, altså: helsekompetanse (engelsk: health literacy).

LITTERATUR:

1. Kickbusch I, Pelikan JM, Apfel F et al., red. Health literacy: the solid facts. WHO Regional Office for Europe. København: World Health Organization, 2013.

http://www.euro.who.int/en/publications/abstracts/health-literacy.-the-solid-facts Lest 20.5.2020.

2. Hva er helsekompetanse og hvilket norsk begrep skal benyttes? I: Strategi for å øke helsekompetansen i befolkningen 2019-2023. Oslo: Helse- og omsorgsdepartementet, 2019: 5 . https://www.regjeringen.no/no/dokumenter/strategi-for-a-oke-helsekompetansen-i-befolkningen-201 9-2023/id2644707/ Lest 20.5.2020.

3. Hem E. Helsekompetanse. I: Store norske leksikon. https://snl.no/helsekompetanse Lest 19.5.2020.

4. Helsekompetanse for «health literacy». I: Statsspråk nr. 4/2019: 2.

https://www.sprakradet.no/globalassets/vi-og-vart/publikasjoner/statssprak/42019/statssprak-4-2019.p df Lest 17.2.2020.

5. Hem E. Termposten - også for leger. Tidsskr Nor Legeforen 2013; 133: 2065. [PubMed][CrossRef]

6. Blikstad-Balas M. Literacy. I: Store norske leksikon. https://snl.no/literacy Lest 19.5.2020.

Publisert: 29. juni 2020. Tidsskr Nor Legeforen. DOI:10.4045/tidsskr.20.0463

(C) Tidsskrift for Den norske legeforening 2020. Lastet ned fra tidsskriftet.no 